\title{
Effect of growth hormone treatment on insulin action in adipocytes from children with Prader-Willi syndrome
}

\author{
Ashraf Kamel, Svante Norgren, Anne-Christine Lindgren ${ }^{3}$, Holger Luthman ${ }^{2}$, Peter Arner ${ }^{1}$ and Claude Marcus \\ Department of Pediatrics, Endocrine Research Unit and ${ }^{1}$ Department of Medicine, Huddinge Hospital, Huddinge, Sweden, and ${ }^{2}$ Department of \\ Molecular Medicine, Rolf Luft Center for Diabetes Research and ${ }^{3}$ Department of Women and Child Health, Karolinska Hospital, Stockholm, Sweden \\ (Correspondence should be addressed to C Marcus, Department of Pediatrics, Endocrine Research Unit, B62, Huddinge University Hospital, \\ Karolinska Institute, S-141 86 Huddinge, Sweden)
}

\begin{abstract}
Objective: To study the effect of growth hormone (GH) treatment (2-4 months) on insulin action in adipocytes isolated from children with Prader-Willi syndrome (PWS), in whom GH deficiency appears to be a primary defect. We investigated the complex effects of GH on carbohydrate metabolism, as part of a current clinical trial of GH treatment in children with PWS.

Methods: Biopsies of subcutaneous abdominal adipose tissue were obtained from 12 children with PWS before and after 2-4 months of GH treatment. Lipogenesis was determined by the incorporation of radiolabelled glucose into lipids in isolated adipocytes, and glycerol release to the incubation medium was used as an index of lipolysis. GLUT4 RNA was measured by solution hybridization.

Results: With low glucose concentrations, at which glucose transport is rate-limiting, maximal insulininduced lipogenesis was increased by $120 \%$ after GH treatment $(P<0.05)$, but the sensitivity to insulin (half-maximum effective hormone concentration) was unchanged. This was not accompanied by a significant change in the RNA expression of GLUT4. Neither responsiveness (maximum effect) nor sensitivity of insulin-induced inhibition of lipolysis was affected by GH treatment.

Conclusions: GH treatment of children with PWS results in an upregulation of insulin-induced lipogenesis in isolated adipocytes, with no effect on insulin-induced inhibition of lipolysis. The data suggest that the site of the effect of GH on lipogenesis is distal to the insulin hormone-receptor interaction, but does not involve altered GLUT4 expression.
\end{abstract}

European Journal of Endocrinology 138 510-516

\section{Introduction}

Prader-Willi syndrome (PWS) is characterized by short stature and obesity and has a prevalence of one in 15000 births (1). Diabetes mellitus similar to the type II form is common in adults with PWS (2). The abnormally low growth hormone $(\mathrm{GH})$ response to stimulation by clonidine, an $\alpha_{2}$-adrenoreceptor agonist, in lean children with PWS indicates that GH deficiency is a primary feature of this syndrome and not secondary to obesity (3). Clinical trials have suggested that pharmacological doses of GH may be effective in increasing linear growth velocity and improving lean body mass in children with PWS (4).

Storage of energy in the form of triglycerides is a key function of white adipose tissue. The fatty acid component in the stored triglycerides is supplied predominantly by circulating lipoproteins, whereas the glycerol phosphate component is obtained from the metabolism of glucose (5). Glucose incorporation into lipids (lipogenesis) is increased by insulin; this effect is due to a combination of stimulated glucose transport and enhanced glucose metabolism (6). The glucose transport across the adipocyte plasma membrane is mediated by a family of carrier proteins, glucose transporters (7). The adipocytes express glucose transporters 1 (GLUT1) and 4 (GLUT4) (8). Almost all GLUT4 is present in intracellular compartments during the basal state, whereas a significant portion of GLUT1 is found in the plasma membrane contributing to the basal transport (7). Insulin induces a redistribution of GLUT4 to the cell surface resulting in augmented glucose transport (9).

Concerns have been raised regarding the effects of GH treatment on carbohydrate metabolism in children of short stature (10). Clinically, no impairment in glucose tolerance is recorded during GH treatment in short stature children with or without GH deficiency, girls with Turner syndrome, and adults with GH deficiency (10-12). In isolated adipocytes, GH, directly or indirectly, produces a wide variety of effects (13). It has a transient insulin-like antilipolytic effect and can induce insulin sensitivity in hypophysectomized rats (14). GH also has a lipolytic effect in most species, including man (15) and may induce insulin resistance (16). Chronic exposure to GH in vitro (adipocyte-derived cell 
line 3T3-F442A) and in vivo (rat adipocytes) decreases the amount of both GLUT1 and GLUT4 present in adipocyte plasma membrane $(17,18)$. Only two studies have been published in which the effect of GH treatment on lipogenesis in isolated human adipocytes was studied. Both studies found no effect on insulin-induced lipogenesis; however, one (19) found a decreased and one (20) found an increased basal lipogenesis.

The risk of glucose intolerance during GH treatment may be greater in obese children with PWS who may already be insulin resistant. In view of the complexity of the effects of $\mathrm{GH}$ on carbohydrate metabolism and discrepancies between previous studies, and as a part of a current clinical trial, our aim was to study the effect of GH treatment (2-4 months) on insulin action in adipocytes isolated from children with PWS.

\section{Patients and methods}

Twelve prepubertal children with PWS participated in the study. Glucose incorporation into lipids and insulininduced inhibition of lipolysis were studied in six children. GLUT4 RNA concentrations were determined in the remaining six children. The mean age of the children was 7 years (range $4-12$ years), and there was no difference in the mean age between the two groups. The amount of fat obtained from each child was not sufficient to permit the study of lipogenesis, lipolysis and GLUT4 RNA in the same children. Ten children were treated with GH $0.1 \mathrm{U} / \mathrm{kg}$ per day and two children were treated with GH $0.2 \mathrm{U} / \mathrm{kg}$ per day. Before the initiation of treatment and after 2-4 months of treatment, an abdominal adipose tissue needle biopsy $(1-2 \mathrm{~g})$ was taken from all 12 children. The last GH injection was given $14 \mathrm{~h}$ before the second biopsy. All biopsies were obtained between $0830 \mathrm{~h}$ and $0930 \mathrm{~h}$ after an overnight fast. The biopsies were taken after local anaesthesia with prilocaine in the surrounding area. The adipocytes were isolated by Rodbell's method (21), washed in Krebs' ringer phosphate buffer (KRP) containing albumin, and the aggregated material removed by filtration through a silk cloth.

The study was approved by the Karolinska Institute Ethics Committee, and informed consent was obtained from the childrens' guardians.

\section{Determination of glucose incorporation into lipids and insulin-induced inhibition of lipolysis}

The lipid incorporation studies were performed at two concentrations of glucose. At the lower concentration $(1 \mu \mathrm{mol} / \mathrm{l})$, glucose transport into the cells is ratelimiting, whereas glucose metabolism becomes ratelimiting at the higher concentrations $(100 \mu \mathrm{mol} / \mathrm{l})$ (6). The adipocytes were incubated at a final concentration of $2 \%(\mathrm{vol} / \mathrm{vol})$ in KRP buffer containing albumin $(40 \mathrm{mg} / \mathrm{ml})$, labelled glucose $\left(\left[3-{ }^{3} \mathrm{H}\right]\right.$ glucose, $5 \times 10^{6}$ c.p.m., $\left.0.2 \mu \mathrm{mol} / \mathrm{l}\right)$, unlabelled glucose $(1 \mu \mathrm{mol} /$ l or $100 \mu \mathrm{mol} / \mathrm{l})$, and insulin $(0-10000 \mu \mathrm{U} / \mathrm{ml})$. Each incubation was performed in duplicate for $2 \mathrm{~h}$ at $37^{\circ} \mathrm{C}$ and stopped by rapid chilling of the vials to $4{ }^{\circ} \mathrm{C}$. To study the insulin-induced inhibition of lipolysis, an aliquot of the medium was removed for analysis of glycerol release, which was determined by a kinetic bioluminescence method and used as an index of lipolysis (22). Incorporation of glucose into lipids was determined as described by Moody et al. (23). Briefly, $45 \mu \mathrm{l} 6 \mathrm{~mol} / \mathrm{l} \mathrm{H}_{2} \mathrm{SO}_{4}$ and $4 \mathrm{ml}$ toluene with 2,5diphenyloxazole were added to each vial. The vials were left at room temperature for $2 \mathrm{~h}$ before the radioactivity was measured by liquid scintillation counting.

The maximal insulin-induced lipogenesis (responsiveness) was calculated from each individual doseresponse curve as the difference between glucose incorporation at the maximum effective stimulatory concentration of insulin minus glucose incorporation in the absence of insulin. The maximal insulin induced-inhibition of lipolysis (responsiveness) was calculated from each individual dose-response curve as the basal glycerol release minus glycerol release at the maximum effective inhibitory concentration of insulin. The concentration of insulin that produced $50 \%$ of the maximum effect ( $\mathrm{EC}_{50}$, sensitivity) was calculated graphically from the individual dose-response curves.

\section{Preparation of RNA}

Total tissue and cellular RNA were purified after homogenization in guanidine isothiocyanate (24).

\section{In vitro synthesis of antisense and sense RNA}

A 142 bp fragment of GLUT4 cDNA was amplified by PCR from pAMT No. 4 using primers flanked with restriction sites and inserted into KpnI and BamHI sites of pGEM3zf + (Promega, Madison, MI, USA). The resulting plasmids were sequenced with an A.L.F. DNA Sequencer (Pharmacia, Uppsala, Sweden). For in vitro synthesis of antisense probe RNA, the plasmids were linearized with EcoRI and transcribed with $\mathrm{SP}_{6}$ RNA polymerase in the presence of ${ }^{35} \mathrm{~S}$-UTP (Amersham, Aylesbury, UK). The products were isolated from unincorporated nucleotides on Sephadex G-50 columns (Nick column, Pharmacia). The transcripts were checked by electrophoresis through a denaturating polyacrylamide gel and exposure to X-ray films. Unlabelled sense standard RNAs were synthesized by linearization of the plasmids with HindIII and transcription with $\mathrm{T}_{7}$ RNA polymerase. After DNase treatment and purification on Sephadex G-50 columns, the RNA concentrations were determined spectrophotometrically, 
taking 1 unit absorbance at $260 \mathrm{~nm}$ to be equivalent to $40 \mu \mathrm{g} / \mathrm{ml}$

\section{Solution hybridization analysis of RNA}

The solution hybridization assay was performed essentially as described previously (25). The expression of $\gamma$-actin RNA was used as an internal control (26).

\section{Northern blot and RNase protection}

The specificity of the probe used in the solution hybridization assay was verified by hybridization of the corresponding ${ }^{32} \mathrm{P}$-labelled cDNA probes to a human multiple-tissue Northern blot membrane (Clonetech Laboratories, Paolo Alto, CA, USA). The probe recognized a single band of expected length and tissue distribution (27) (Fig. 1A). In addition, an RNase protection assay was performed with hybridization conditions identical to those in effect during the quantitative experiments. The protected fragments were analysed by electrophoresis on a $4 \%$ denaturing polyacrylamide gel. Again, a specific band of the expected length was observed (Fig. 1B).

\section{Statistics}

Differences between the groups were assessed using Student's paired $t$-test. $P$ values less than 0.05 were considered to be significant.

\section{Results}

The clinical characteristics of the 12 children with PWS who participated in the study are presented in Table 1. The puberty staging was according to Tanner. The body mass index (BMI) was calculated using the formula weight $/$ height ${ }^{2}\left(\mathrm{~kg} / \mathrm{m}^{2}\right)$. The height increased significantly after GH treatment, whereas weight and BMI did not change significantly.

The mean fat cell volume was $549.8 \pm 182.7 \mathrm{pl}$ before and $456.5 \pm 188 \mathrm{pl}$ after $\mathrm{GH}$ treatment $(P=0.059)$. Because estimates of fat cell metabolism depend on the size of the cells (28), we present our data as "per cell surface area'. With both glucose concentrations tested, basal lipogenesis in the absence of insulin was unaffected by $\mathrm{GH}$ treatment. However, the ability of insulin to stimulate lipogenesis was significantly enhanced. With the low glucose concentration

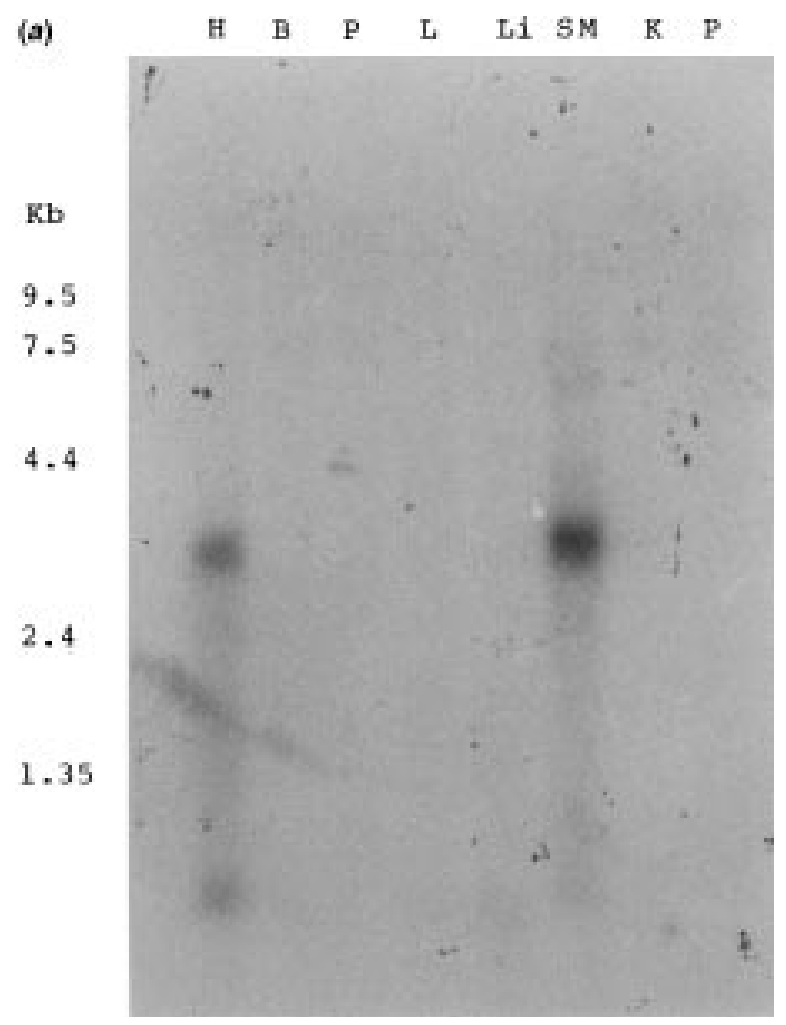

(b)

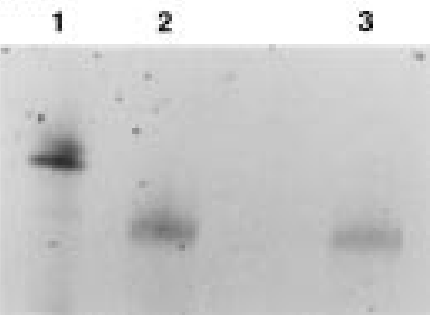

Figure 1 Confirmation of probe specificity. (a) Northern blot. A human multiple-tissue Northern blot membrane was blotted with the ${ }^{32} \mathrm{P}$ labelled GLUT4 cDNA probe. H, heart; B, brain; P, placenta; L, lung; Li, liver, SM, skeletal muscle; K, kidney; P, pancreas. The specific band recognized by the probe and the tissue distribution were in agreement with previous reports of GLUT4 RNA (27). (b) RNase protection assay. Polyacrylamide gel electrophoresis of radiolabelled RNA probe and nuclease-resistant hybrids. Experiments were performed as described in Patients and methods. Bands correspond to GLUT4 probe alone (1) and ribonuclease-protected probe after hybridization with GLUT4 standard RNA (2) or with total RNA from adipose tissue (3). 
Table 1 Anthropometric data and IGF-I concentrations in prepubertal patients (eight boys and four girls) aged 7 (4-12) years) at entry to the study. Values are means \pm S.D.

\begin{tabular}{lcccc}
\hline & $\begin{array}{c}\text { Height } \\
(\mathrm{m})\end{array}$ & $\begin{array}{c}\text { Weight } \\
(\mathrm{kg})\end{array}$ & $\begin{array}{c}\text { BMI } \\
\left(\mathrm{kg} / \mathrm{m}^{2}\right)\end{array}$ & $\begin{array}{c}\text { IGF-I } \\
(\mu \mathrm{g} / \mathrm{ml})\end{array}$ \\
\hline Before GH treatment & $1.2 \pm 0.02$ & $31.2 \pm 14.2$ & $20.5 \pm 2.9$ & $111.3 \pm 35.3$ \\
After 2-4 months of GH treatment & $1.24 \pm 0.02^{\mathrm{a}}$ & $32.1 \pm 14.5$ & $19.9 \pm 3.4$ & $380.8 \pm 101.8^{\mathrm{b}}$ \\
\hline
\end{tabular}

${ }^{\mathrm{a}} P<0.0001,{ }^{\mathrm{b}} P<0.00001$, compared with before treatment.

$(1 \mu \mathrm{mol} / \mathrm{l})$, with which glucose transport is the ratelimiting step, the glucose incorporation into lipids was significantly increased after GH treatment (Fig. 2A). The maximum insulin-induced incorporation of glucose was $1 \pm 0.6$ and $2.1 \pm 1.1 \mu \mathrm{mol} / \mu \mathrm{m}^{2} / 2 \mathrm{~h} \times 10^{-11}$ before and after $\mathrm{GH}$ treatment respectively $(P=0.02)$. With the high glucose concentration $(100 \mu \mathrm{mol} / \mathrm{l})$, the insulininduced glucose incorporation was also increased after $\mathrm{GH}$ treatment, but the difference was not significant $(P=0.078$; Fig. $2 B)$. The insulin sensitivity was not affected by GH treatment. With a low concentration of glucose, the mean $\mathrm{EC}_{50}$ was $7.2 \pm 9.7 \mu \mathrm{U} / \mathrm{ml}$ before and $4.9 \pm 2 \mu \mathrm{U} / \mathrm{ml}$ after $\mathrm{GH}$ treatment $(P=0.559)$. With high glucose concentrations, the $\mathrm{EC}_{50}$ was $2.3 \pm 3.8 \mu \mathrm{U} /$ $\mathrm{ml}$ before and $3.3 \pm 3.4 \mu \mathrm{U} / \mathrm{ml}$ after $\mathrm{GH}$ treatment $(P=0.685)$. With both glucose concentrations, neither the sensitivity nor the responsiveness of insulin-induced inhibition of lipolysis was significantly affected (Table 2).

The stimulation of insulin-induced lipogenesis by GH treatment may be explained by an upregulation of the glucose transporter system. To investigate this, we established a solution hybridization RNase-protection method to determine the RNA levels of GLUT4. Briefly, the hybridization signal from RNA extracts was compared with a standard curve constructed with increasing amounts of in vivo transcribed sense standard RNA. All RNA quantifications were within the linear range of the standard curves. Figure 3 shows a standard curve obtained by hybridization of ${ }^{35}$ S-labelled antisense GLUT4 RNA to increasing amounts of unlabelled standard sense RNA. In a parallel experiment, increasing amounts of unlabelled sense RNA were hybridized with the probe in the presence of an extract containing $1.3 \mu \mathrm{g}$ total RNA from human adipose tissue. Conversely, increasing amounts of total RNA extracted from human adipose tissue were hybridized to the labelled GLUT4 antisense probe (Fig. 3, insert). The hybridization signal was linear in the range (1.3-10.4 $\mu \mathrm{g})$ of total RNA.

The levels of expression of GLUT4 RNA in adipocytes and adipose tissue were not significantly altered after
(A)
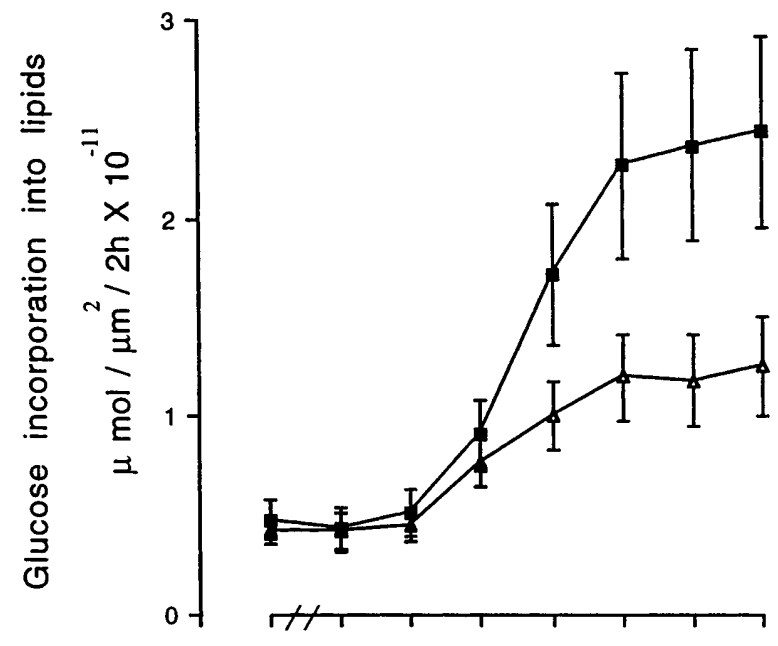

$\begin{array}{llllllll}0 & 10^{-2} & 10^{-1} & 1 & 10^{1} & 10^{2} & 10^{3} & 10^{4}\end{array}$
(B)

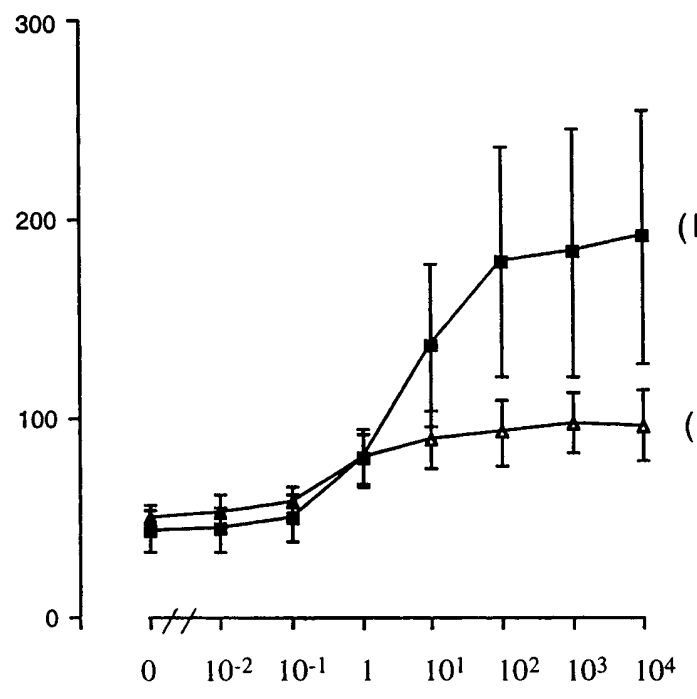

(II)

\section{Insulin concentration $\mu \mathrm{U} / \mathrm{mL}$}

Figure 2 Effect of increasing concentrations of insulin on glucose incorporation into lipids, expressed per cell surface area $\left(\mu \mathrm{mol} / \mu \mathrm{m}^{2} / 2 \mathrm{~h} \times 10^{-11}\right)$, before (I) and after (II) GH treatment in children with PWS. (A) Low glucose concentration $(1 \mu \mathrm{mol} / /)$. (B) High glucose concentration $(100 \mu \mathrm{mol} / \mathrm{l})$. 
Table 2 Sensitivity $\left(E C_{50}\right)$ and responsiveness (maximum insulin-induced inhibition of lipolysis). Values are means \pm S.D.

\begin{tabular}{lccccc}
\hline \multirow{2}{*}{ Glucose concentration } & \multicolumn{2}{c}{ Sensitivity } & & \multicolumn{2}{c}{ Responsiveness } \\
\cline { 2 - 3 } & Before GH & After GH & & Before GH & After GH \\
\hline Low glucose $(1 \mu \mathrm{mol} / \mathrm{l})(n=6)$ & $0.6 \pm 0.3$ & $0.5 \pm 0.3$ & & $2.3 \pm 1.8$ & $3.0 \pm 0.3$ \\
High glucose $(100 \mu \mathrm{mol} / \mathrm{l})(n=6)$ & $0.5 \pm 0.3$ & $0.7 \pm 0.4$ & & $3.0 \pm 1.7$ & $2.9 \pm 2.0$ \\
\hline
\end{tabular}

No significant differences were found in the sensitivity or responsiveness of insulin-induced inhibition of lipolysis, at any of the glucose concentrations tested, before and after 2-4 months of GH treatment.

2-4 months of $\mathrm{GH}$ treatment. The mean levels of GLUT4 RNA in adipocytes were $352.3 \pm 136.3$ and $393.5 \pm 221.8$ copies/pg total RNA before and after treatment, respectively (Fig. 4A). Those of GLUT4 RNA in adipose tissue samples were $162 \pm 85.6$ and $215.5 \pm 148.8$ copies/pg total RNA before and after treatment respectively (Fig. 4B). As an internal control of the integrity of the RNA extracts, the levels of $\gamma$ actin RNA in both adipocytes and adipose tissue were determined (Table 3).

\section{Discussion}

GH may modify glucose turnover in many ways, directly and indirectly via induction of insulin-like growth factor (IGF)-I (29). Transient insulin-like effects have been reported during short-term infusions of $\mathrm{GH}$ in humans (30). Similar effects have been observed in vitro in rodent adipocytes $(31,32)$, but not in human cells (13).

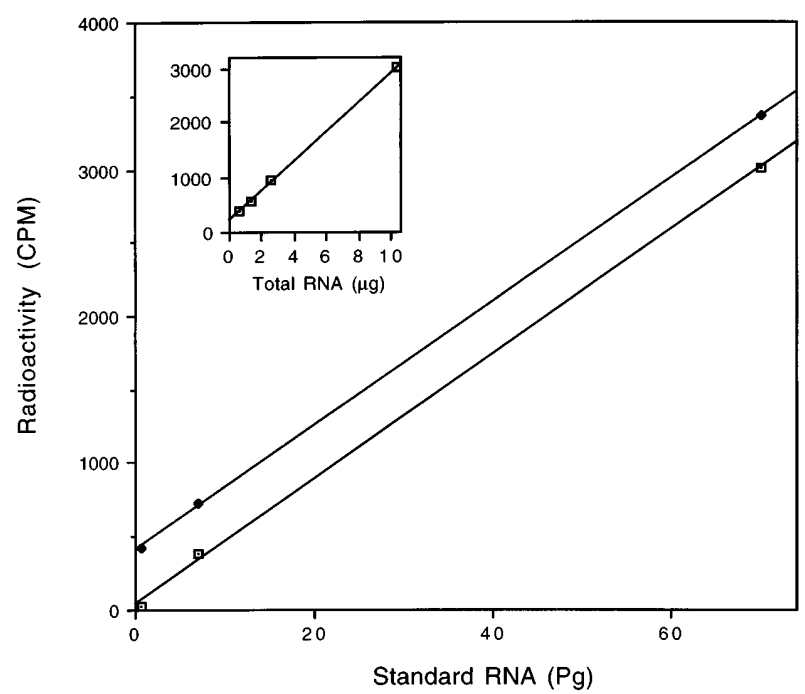

Figure 3 Non-saturation solution hybridization experiments with GLUT4 probe. The ${ }^{35} \mathrm{~S}$-labelled antisense RNA probe was hybridized to increasing amounts of in vitro transcribed sense RNA which was used as standard in the experiments $(\square)$. The probe was also hybridized with increasing amounts of in vitro transcribed sense RNA in the presence of a total RNA extract containing $1.3 \mu \mathrm{g}$ RNA isolated from adipocytes $(\bullet)$. Inset: Linear hybridization response to an adipocyte RNA extract.
After the first hours of infusion, GH induces a marked decrease in glucose uptake, with both hepatic and peripheral insulin resistance $(14,33,34)$. During longer treatments with low doses of $\mathrm{GH}$, the insulin resistance is partly reversible $(35,36)$. Higher doses, however, cause persistent insulin resistance (34) mimicking the insulin resistance of acromegaly (16).

In the present study, we found that GH treatment for 2-4 months stimulated lipogenesis in abdominal adipocytes of children with PWS. The enhanced glucose incorporation reached significance only with a low concentration of glucose $(1 \mu \mathrm{mol} / \mathrm{l})$, at which glucose transport is rate-limiting for incorporation of glucose into lipids, and the largest fraction of glucose entering the adipocytes is incorporated into triglyceride-glycerol $(6,37-39)$. With the higher concentration of glucose $(100 \mu \mathrm{mol} / \mathrm{l})$, metabolic steps beyond the glucose transport are rate-limiting, and most of the glucose is converted into lactate $(6,37-39)$. The enhanced lipogenesis is probably not a direct effect of $\mathrm{GH}$ on the adipocytes. When the effects of GH have been studied in skeletal muscles, adipocytes and fibroblasts in vitro, a decreased glucose uptake/lipogenesis has been observed after the insulin-like effects during the first hours of incubation $(14,40,41)$. Instead, the direct effects of GH on glucose transport and tissue responsiveness to insulin are probably opposed by other metabolic processes that enhance insulin action in adipose tissue. In this study, we found no significant decrease in BMI after 2-4 months of GH treatment. However, BMI does not discriminate between fat and muscle mass. $\mathrm{GH}$ treatment in $\mathrm{GH}$-deficient adults decreased body fat and increased lean body mass as determined by computed tomography and bioelectrical impedance (36). Thus increased lean body mass or altered body fat localization may mediate the observed stimulation of lipogenesis.

A previous in vitro study of fat cell metabolism reported a decreased basal lipogenesis in abdominal adipocytes, with no effect on gluteal fat depots after 2-3 months of GH treatment in GH-deficient children (19). However, when the same investigators used identical conditions to study the effects of GH treatment on children with short stature but without GH deficiency, lipogenesis was upregulated in gluteal adipocytes but unchanged in adipocytes from the abdominal depots 
A

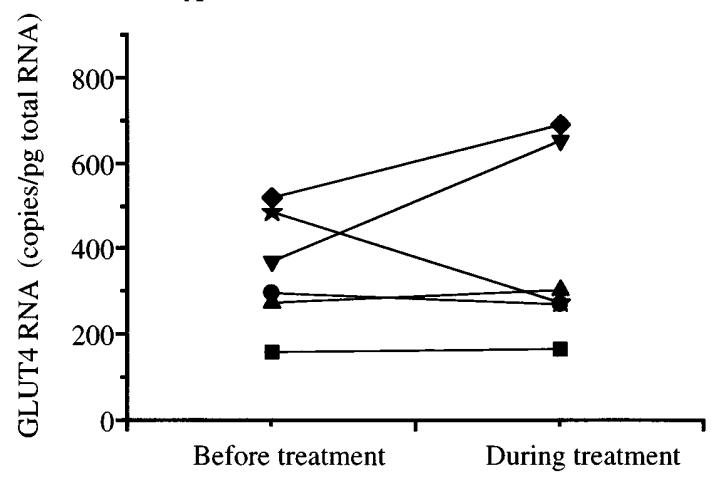

B

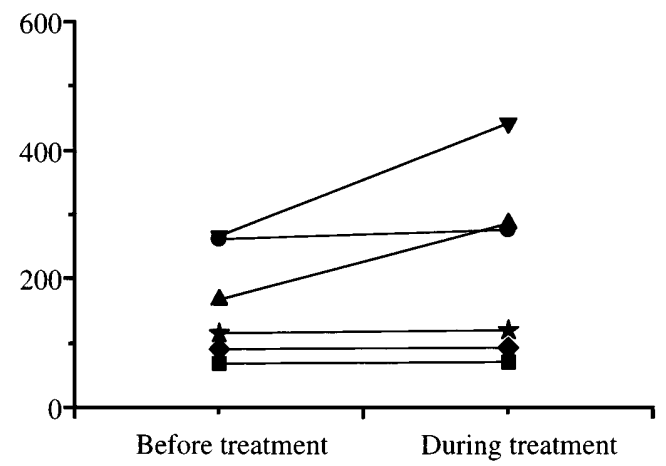

Figure 4 Levels of GLUT4 mRNA in isolated adipocytes (A) and adipose tissue samples (B) from children with PWS before and during GH treatment.

(20). In both studies, GH treatment had no effect on insulin-induced lipogenesis. One reason for the discrepancies between these two studies and the results presented here may be the method of calculation of lipogenesis. In the previous studies, GH therapy was associated with a reduction in abdominal adipocyte size, and to present metabolic events 'per cell' may thus be misleading (28). However, we cannot exclude the possibility that adipocytes in PWS children are more sensitive to alterations in body composition and therefore react differently. Another interesting possibility is that the timing of the GH peaks is of importance. In the present study, the adipose tissue biopsy was taken $12 \mathrm{~h}$ after the last GH injection, whereas in the previous two studies, the biopsies were taken after $36 \mathrm{~h}$.

We found no difference in the sensitivity of insulininduced lipogenesis or insulin-induced inhibition of lipolysis after GH treatment, indicating that the observed increase in the maximal insulin-induced lipogenesis is a post-binding effect. This is further supported by the finding that one insulin-receptor mediated effect, lipogenesis, is enhanced whereas another, anti-lipolysis, is unchanged. The effect of GH on lipogenesis was only significant under conditions in which the rate-limiting step was glucose transport. GLUT4, present in intracellular compartments during the basal state, is responsible for the insulin-stimulated

Table $3 \gamma$-Actin RNA levels in adipose tissue or adipocytes of children with PWS, before and after GH treatment. Values are means \pm S.D.

\begin{tabular}{lcc}
\hline & \multicolumn{2}{c}{ Actin RNA (copies/pg total RNA) } \\
\cline { 2 - 3 } & Before GH & After GH \\
\hline Adipose tissue $(n=5)$ & $765.0 \pm 176.9$ & $712.2 \pm 135.1$ \\
Adipocytes $(n=5)$ & $931.8 \pm 138.2$ & $854.6 \pm 130.3$ \\
\hline
\end{tabular}

No significant difference was found before and after 2-4 months of $\mathrm{GH}$ treatment in either adipose tissue samples or isolated adipocytes. glucose uptake after translocation to the plasma membrane (42). It seemed reasonable to suspect that the increase in glucose transport after $\mathrm{GH}$ treatment might have been secondary to increased GLUT4. However, we found no increase in GLUT4 RNA. Previous reports have concluded that chronic GH treatment of 3T3-F442A adipocytes and rat adipocytes affects the redistribution of GLUT4, with no effect on the level of expression $(17,18)$. A similar mechanism may explain our results.

In conclusion, GH treatment of children with PWS results in an upregulation of the maximum insulininduced lipogenesis in isolated adipocytes, with no effect on basal lipogenesis or insulin-induced inhibition of lipolysis.

\section{Acknowledgements}

This work was supported by grants from the Swedish Medical Research Council (11332-19X 9941 and 1034), Karolinska Institute, the Foundations of Crown Princess Lovisa/Thileman, Sven Jerrings, Samariten, Wera Ekström, Gunvor and Josef Anérs, Frimurare Barnhuset and Lilly Sweden AB.

\section{References}

1 Butler MG. Prader-Willi syndrome: current understanding of cause and diagnosis. American Journal of Medical Genetics 199035 319-322.

2 Kousholt AM, Beck-Nielsen H \& Lund HT. A reduced number of insulin receptors in patients with Prader-Willi syndrome. Acta Endocrinologica 1983104 345-351.

3 Lee P, Wilson D, Rountree L, Hintz R \& Rosenfeld R. Linear growth response to exogenous growth hormone in Prader-Willi syndrome. American Journal of Medical Genetics 198728 865-871.

4 Connor EL \& Rosenbloom A. Effects of growth hormone in Prader-Willi syndrome. Clinical Pediatrics 199332 296-297.

5 Digirolamo M \& Fried SK. In vitro metabolism of adipocytes. In Biology of the Adipocytes. Research Approaches, pp 120-147. Eds GJ Hausman \& R Martin. New York: Van Nostrand Reinhold Co., 1987.

6 Arner P \& Engfeldt P. Fasting-mediated alteration studies in insulin action on lipolysis and lipogenesis in obese women. American Journal of Physiology 1987253 E193-E201. 
7 Piper RC, Hess LJ \& James DE. Differential sorting of two glucose transporters expressed in insulin-sensitive cells. American Journal of Physiology 1991260 C570-C580.

8 James DE, Strube M \& Mueckler M. Molecular cloning and characterization of an insulin-regulatable glucose transporter Nature 1989338 83-87.

9 Holman GD, Kozka IJ, Clark AE, Flower CJ, Saltis J, Habberfield AD, Simpson IA \& Cushman SW. Cell surface labelling of glucose transporter isoform GLUT4 by bis-mannose photolabel. Journal of Biological Chemistry $199026518172-18179$.

10 Walker J, Chaussain JL \& Bougneres PF. Growth hormone treatment of children with short stature increases insulin secretion but does not impair glucose disposal. Journal of Clinical Endocrinology and Metabolism 198969 253-258.

11 Saenger P, Attie KM, Dimartino-Nardi J \& Fine RN. Carbohydrate metabolism in children receiving growth hormone for 5 years. Chronic renal insufficiency compared with growth hormone deficiency, Turner syndrome, and idiopathic short stature. Pediatric Nephrology 199610 261-263.

12 Jorgensen JOL, Thuesen L, Muller J, Ovesen P, Skakkebaek NE \& Christiansen JS. Three years of growth hormone treatment in growth hormone deficient adults: near normalization of body composition and physical performance. European Journal of Endocrinology $1994130224-228$.

13 Marcus C, Margery V, Kamel A \& Brönnegård M. Effects of growth hormone on lipolysis in humans. Acta Paediatrica Supplement $199440654-58$

14 Dimitriadis G, Parry-Billings M, Leighton B, Piva T, Dunger D \& Calder P. Studies on the effects of growth hormone administration in vivo on the rates of glucose transport and utilization in rat skeletal muscle. European Journal of Clinical Investigation 199424 $161-165$.

15 Marcus C, Bolme P, Micha-Johanson G, Margery V \& Brönnegård M. Growth hormone increases the lipolytic sensitivity for catecholamines in adipocytes from healthy adults. Life Science 199454 1335-1341.

16 Bolinder J, Östman J, Werner S \& Arner P. Insulin action in human adipose tissue in acromegaly. Journal of Clinical Investigation 198677 1201-1206.

17 Ku Tai PK, Liao JF, Chen EH, Dietz J, Schwartz J \& Carter-Su C. Differential regulation of two glucose transporters by chronic growth hormone treatment of cultured 3T3-F442A adipose cells. Journal of Biological Chemistry 1990265 21828-21834.

18 Kilgour E, Baldwin SA \& Flint DJ. Divergent regulation of rat adipocyte GLUT1 and GLUT4 glucose transporters by GH. Journal of Endocrinology 1995145 27-33.

19 Rosenbaum M, Gertner JM \& Leibel RL. Effects of systemic growth hormone $(\mathrm{GH})$ administration on regional adipose tissue distribution and metabolism in GH-deficient children. Journal of Clinical Endocrinology and Metabolism 198969 1274-1280.

20 Rosenbaum M, Gertner JM, Gidfar N, Hirsch J \& Leibel RL. Effects of systemic growth hormone $(\mathrm{GH})$ administration on regional adipose tissue distribution in children with non-GH-deficient short stature. Journal of Clinical Endocrinology and Metabolism $199275151-156$

21 Rodbell M. Metabolism of isolated fat cells. Effects of hormones on glucose metabolism and lipolysis. Journal of Biological Chemistry $1964239375-380$.

22 Hellmér J, Arner P \& Lundin A. Automatic luminometric kinetic assay of glycerol for lipolysis studies. Analytical Biochemistry 1989 $177132-137$

23 Moody AJ, Stan MA, Stan M \& Gliemann J. A simple free fat cell bioassay for insulin. Hormone and Metabolic Research $1974612-$ 16.

24 Chomczynski P \& Sacchi N. Single-step method of RNA isolation by acid guanidinium thiocyanate-phenol-chloroform extraction. Analytical Biochemistry 1987162 156-159.

25 Durnam DM \& Palmiter RD. A practical approach for quantitating specific mRNAs by solution hybridization. Analytical Biochemistry $1983131385-393$
26 Erba HP, Gunning P \& Kedes L. Nucleotide sequence of the human gamma cytoskeletal actin mRNA: anomalous evolution of the vertebrate non-muscle actin genes. Nucleic Acids Research 1986 14 5275-5294.

27 Garvey WT, Maianu L, Huecksteadt TP, Birnbaum MJ, Molina JM \& Ciaraldi TP. Pretransitional suppression of a glucose transporter protein causes insulin resistance in adipocytes from patients with non-insulin-dependent diabetes mellitus and obesity. Journal of Clinical Investigation 199187 1072-1081.

28 Marcus C, Karpe B, Bolme P, Sonnenfeld T \& Arner P. Changes in catecholamine-induced lipolysis in isolated human fat cells during the first year of life. Journal of Clinical Investigation 1987 79 1812-1818.

29 Hussain MA, Schmitz O, Mengel A, Glatz Y \& Christiansen JS. Comparison of the effects of growth hormone and insulin-like growth factor 1 in growth hormone-deficient humans. Journal of Clinical Investigation 199494 1126-1133.

30 Adamson U \& Efendic S. Insulin-like and diabetogenic effects of growth hormone in healthy subjects, diabetics, and low insulin responders. Journal of Clinical Endocrinology and Metabolism 1979 49 456-461.

31 Adamafio NA \& Frank MN. Effects of growth hormone on lipogenesis and glucose oxidation in genetically GH-deficient mice. Molecular and Cellular Endocrinology 198437 241-244.

32 Landron D, Guerre-Milio M, Postel-Vinay MC \& Lavau M. Relationship between increased binding and insulin-like effects of human growth hormone in adipocytes from young fa/fa rats. Endocrinology 1989124 2305-2313.

33 O'Neal DN, Kalfas A, Dunning PL, Christopher MJ, Sawyer SD, Ward GM \& Alford FP. The effects of 3 months of recombinant human growth hormone $(\mathrm{GH})$ therapy on insulin and glucosemediated glucose disposal and insulin secretion in GH-deficient adults: a minimal model analysis. Journal of Clinical Endocrinology and Metabolism 199479 975-983.

34 Rizza RA, Mandarino LJ \& Gerich JE. Effects of growth hormone on insulin action in man: mechanisms of insulin resistance, impaired suppression of glucose production and impaired stimulation of glucose utilization. Diabetes $198231663-669$.

35 Lippe BM, Kaplan SA, Golden MP, Hendricks SA \& Scott ML. Carbohydrate tolerance and insulin receptor binding in children with hypopituitarism: responses after acute and chronic human growth hormone administration. Journal of Clinical Endocrinology and Metabolism 198153 507-513.

36 Fowelin J, Attvall S, Lager I \& Bengtsson B-Å. Effects of treatment with recombinant human growth hormone on insulin sensitivity and glucose metabolism in adults with growth hormone deficiency. Metabolism 199342 1443-1447.

37 Gliemann J, Rees WD \& Foley JA. The fate of labeled glucose molecules in the rat adipocyte. Dependence on glucose concentration. Biochimica et Biophysica Acta 1984804 68-76.

38 Kashiwagi A, Verso MA, Andrews J, Vasques B, Reaven G \& Foley JE. In vitro insulin resistance of human adipocytes isolated from subjects with non-insulin-dependent diabetes mellitus. Journal of Clinical Investigation 198372 1246-1254.

39 Tozzo E, Shepherd PR, Gundi L \& Kahn BB. Transgenic GLUT-4 overexpression in fat enhances glucose metabolism: preferential effect on fatty acid synthesis. American Journal of Physiology 1995 268 E956-E964.

40 Nyberg G, Boström S, Johansson R \& Smith U. Reduced glucose incorporation to triglycerides following chronic exposure of human fat cells to growth hormone. Acta Endocrinologica 198095 129-133.

41 Takeda S, Podskalny JM \& Gorden P. Direct effect of growth hormone to inhibit glucose uptake in cultured human fibroblasts. Metabolism 198433 658-661.

42 Cheatham B \& Khan CR. Insulin action and the insulin signalling network. Endocrine Reviews 199516 117-142.

Received 28 August 1997

Accepted 5 February 1998 